University of Nebraska - Lincoln

DigitalCommons@University of Nebraska - Lincoln

Agronomy \& Horticulture - Faculty Publications

Agronomy and Horticulture Department

$5-2002$

\title{
Accumulation of Microbial Biomass within Particulate Organic Matter of Aging Golf Greens
}

\author{
Mine Kerek \\ University of Nebraska-Lincoln \\ Rhae A. Drijber \\ University of Nebraska-Lincoln, rdrijber1@unl.edu \\ William L. Powers \\ University of Nebraska-Lincoln \\ Robert C. Shearman \\ University of Nebraska-Lincoln, rshearman1@unl.edu \\ Roch E. Gaussoin \\ University of Nebraska-Lincoln, rgaussoin1@unl.edu
}

See next page for additional authors

Follow this and additional works at: https://digitalcommons.unl.edu/agronomyfacpub

Part of the Agricultural Science Commons, Agriculture Commons, Agronomy and Crop Sciences Commons, Botany Commons, Horticulture Commons, Other Plant Sciences Commons, and the Plant Biology Commons

Kerek, Mine; Drijber, Rhae A.; Powers, William L.; Shearman, Robert C.; Gaussoin, Roch E.; and Streich, Anne, "Accumulation of Microbial Biomass within Particulate Organic Matter of Aging Golf Greens" (2002). Agronomy \& Horticulture -- Faculty Publications. 1071.

https://digitalcommons.unl.edu/agronomyfacpub/1071

This Article is brought to you for free and open access by the Agronomy and Horticulture Department at DigitalCommons@University of Nebraska - Lincoln. It has been accepted for inclusion in Agronomy \& Horticulture -Faculty Publications by an authorized administrator of DigitalCommons@University of Nebraska - Lincoln. 


\section{Authors}

Mine Kerek, Rhae A. Drijber, William L. Powers, Robert C. Shearman, Roch E. Gaussoin, and Anne Streich 


\title{
GREENS MANAGEMENT
}

\section{Accumulation of Microbial Biomass within Particulate Organic Matter of Aging Golf Greens}

\author{
Mine Kerek, Rhae A. Drijber,* William L. Powers, Robert C. Shearman, Roch E. Gaussoin, \\ and Anne Marie Streich
}

\begin{abstract}
Microbial biomass (MB) is a key variable controlling soil organic matter dynamics in soil. Currently, there is little information on the amount and significance of MB in highly managed golf greens. Our objective was to determine the amount and distribution of $\mathrm{MB}$ within soil structural components of golf greens and its relationship to the location of organic substrates. During 1996, 47 greens were sampled from 12 golf courses within Nebraska (USA). Microbial biomass, determined as extractable lipid phosphate on field-moist soils, increased linearly with age of green $\left(Y=19.39+3.54 x ; r^{2}=0.87, P=\right.$ 0.001). In 1997 and 1999, selected greens were resampled and separated into mineral fraction (MF) and particulate organic matter (POM) fraction using a sodium metatungstate (NMT; $r=2.3 \mathrm{~g} \mathrm{~cm}^{-3}$ ). Then, POM was separated into light (L-POM) and heavy (H-POM) fractions using NMT $\left(r=2.0 \mathrm{~g} \mathrm{~cm}^{-3}\right)$. Amount of MB of whole soil and POM was linearly related to green age $\left(r^{2}=0.76\right.$ and 0.68 , respectively). Amount of MB in MF was not related to green age. The portion of total soil MB associated with POM increased significantly from $\mathbf{2 5 . 6} \%$ for an $\mathbf{8}$-yr-old green to $\mathbf{7 7 . 8} \%$ for a $\mathbf{2 8}$-yr-old green. Carbon in fulvic acid and humic acid increased with green age from 0.5 to 1.7 and 0.6 to $2.6 \mathrm{~g} \mathrm{~kg}^{-1}$ soil, respectively. As humus is a relatively stable form of soil organic matter, we hypothesized that humus accumulation within POM renders both POM and associated MB more resistant to degradation; thus, they accumulate.
\end{abstract}

G OLF GREENS ARE TURF SURFACES constructed of very sandy soil mixtures. Soil processes important for maintaining healthy turfgrass, such as organic matter degradation, nutrient supply, $\mathrm{N}$ fixation, mycorrhizal colonization, and disease occurrence and suppression, are mediated by the soil microbial biomass (MB) (Alexander, 1977; Nelson, 1992, 1994; Gregorich et al., 1994; Turgeon, 1996). Microbial biomass also serves as a labile source of organic matter (Gregorich et al., 1994) and as a source and sink for the major plant nutrients. Therefore, $\mathrm{MB}$ is essential to turfgrass health and long-term green productivity (Nelson, 1994). Despite its known importance, there is little information on the amount and significance of $\mathrm{MB}$ in golf greens. Populations of total fungi and total bacteria, as well as selected microbial groups, have been enumerated in golf greens by plating onto various media (Mancino et al., 1993; Liu et al., 1995; Elliott and Des Jardin, 1999a, 1999b). A bias is instantly introduced into the analysis when using

Dep. of Agron. and Hortic., 279 Plant Science, Univ. of Nebraska, Lincoln, NE 68583-0915. Journal Paper no. 12775 of the Agric. Res. Div., Univ. of Nebraska, Lincoln. Received 21 June 2000. *Corresponding author (rdrijber1@unl.edu).

Published in Agron. J. 94:455-461 (2002). a culturable method as one obtains only those organisms that can be cultured on a particular medium under defined conditions (Elliott and Des Jardin, 1999b). Therefore, cultural techniques significantly underestimate the MB of golf greens. An alternative method of determining $\mathrm{MB}$ is based on extraction of cellular components (e.g., phospholipids) from cells within the soil (Frostegård et al., 1991). This method does not rely on recovery of intact, viable, and culturable cells but requires quantitative extraction of cellular components from cells within the soil and selection of appropriate conversion factors to calculate MB (Hill et al., 1993). Although this approach has not been applied to golf greens, it has been used successfully to quantify MB in other ecosystems (Findlay et al., 1989; Frostegård et al., 1991; Hill et al., 1993; Jordan et al., 1995; Drijber et al., 2000).

Microbial biomass and its products may be associated with free primary soil particles (i.e., sand, silt, and clay), aggregates, and macroorganic matter (Tisdall and Oades, 1982; Ahmed and Oades, 1984; Kanazawa and Filip, 1986; Beare et al., 1990; Gregorich and Janzen, 1996). The location of microorganisms in the soil structure has been studied by different methods, such as electron microscopy (Foster, 1988), repeated washing of soil aggregates (Hattori, 1988), or by methods involving physical soil fractionation and density separation (Turchenek and Oades, 1979; Monrozier et al., 1991; Christensen, 1992). Factors determining the distribution of microorganisms in the soil structure, such as substrate location, clay content, microaggregation, and resistance to drying, have been used to explain microbial survival in soils (Van Gestel et al., 1996). In highly sandy soils, such as golf greens, mechanisms promoting the development, survival, and beneficial activities of MB are largely unknown. Thus, our objective was to determine the amount and distribution of MB within soil structural components of golf greens and its relationship to the location of organic substrates.

\section{MATERIALS AND METHODS}

\section{Soil Samples}

The study consisted of 47 golf greens sampled during the fall of 1996 from 12 golf courses located within Nebraska (USA). Of the 47 greens, six selected greens were resampled

Abbreviations: CC, country club; FA-C, fulvic acid carbon; HA-C, humic acid carbon; H-POM, heavy particulate organic matter; lipid-P, extractable lipid phosphate; L-POM, light particulate organic matter; $\mathrm{MB}$, microbial biomass; MF, mineral fraction; NMT, sodium metatungstate; POM, particulate organic matter. 
from five courses in the fall of 1997, and an additional six greens were resampled from three courses in the spring of 1999. Soils from 10 or more cores $(2 \mathrm{~cm}$ in diam. by $15 \mathrm{~cm}$ in depth) were composited from each green after removal of grass thatch. Soils were kept on ice for transport to the lab where they were refrigerated for less than a week before the removal of visible roots and sieving to $4 \mathrm{~mm}$. During sieving, numerous sand particles were attached to the roots, and thus stayed on the sieve. In order to include these particles in the soil mixture, material staying on the sieve was air-dried for a few hours while refrigerating material passing through the sieve. After a second sieving, excluding roots as much as possible, particles passing through the sieve were mixed with previously sieved soil material. After mixing to homogenize, the sample was divided into two parts. One part was subsampled immediately for $\mathrm{MB}$ determination, with the remaining soil frozen field-moist at $-22^{\circ} \mathrm{C}$. The second part was air-dried and sieved to $2 \mathrm{~mm}$ for further physical and chemical analyses, including MB determination on soil density fractions.

Basic soil characterization was done by the University of Nebraska Soil and Plant Analytical Laboratory. Particle size distribution was determined by the hydrometer method (Gee and Bauder, 1986), total soil $\mathrm{C}$ and $\mathrm{N}$ were determined by dry combustion using LECO FP-2000 C and N analyzer (LECO Corp., St. Joseph, MI), and pH was determined in a 1:1 soil/ water mixture (Thomas, 1996).

\section{Subsampling Procedure for Soil Density Fractionation}

Air-dried soil $<2 \mathrm{~mm}$ was rolled back and forth on a large piece of paper in all directions and then gently spread out in a flat circle of about $1-\mathrm{cm}$ thickness. Both soil particle size and amount of plant material seemed to increase from innerto outermost part of the circle. Thus, to be representative, a complete wedge-shaped subsample large enough to provide the required amount of soil was removed from the circle. In other words, for different amounts of soil samples needed, only the curvature length (not the radius) of the wedge was changed. Duplicates were subsampled in the same manner from the remaining soil in the circle.

\section{Separation of Particulate Organic Matter}

By definition, particulate organic matter (POM) is separated from the soil mineral fraction $(\mathrm{MF})$ by dispersion in hexametaphosphate and sieving to $53 \mu \mathrm{m}$ (Cambardella and Elliott, 1992). Material remaining on the sieve, corrected for sand, is called POM while material passing through the sieve is termed MF. Density fractionation often precedes dispersion and sieving to isolate free POM, i.e., that occurring between aggregates (Golchin et al., 1995; Cambardella and Elliott, 1993; Jastrow et al., 1996). Because our objective was to separate soil fractions without redistribution of $\mathrm{MB}$, the soil was not dispersed in hexametaphosphate. Furthermore, because few soil particles from these highly sandy greens would pass a $53-\mu \mathrm{m}$ sieve, density separation alone was used to separate POM from MF (Fig. 1). Soil samples were taken in duplicate for MB determinations. However, because we obtained very little variation between the replicates for humus $\mathrm{C}$ determination, only a few samples were duplicated for this analysis. Airdried soil samples $<2 \mathrm{~mm}$ ( $25 \mathrm{~g}$ for humus $\mathrm{C}$ and $10 \mathrm{~g}$ for MB determination) were placed in a $250-\mathrm{mL}$ centrifuge bottle to which $150 \mathrm{~mL}$ of sodium metatungstate (NMT) solution $\left(3 \mathrm{Na}_{2} \mathrm{WO}_{4} \cdot 9 \mathrm{WO}_{3}\right.$, Aldrich Chem. Co., St. Louis) with a density of $2.3 \mathrm{~g} \mathrm{~cm}^{-3}$ was added (Shaymukhametov et al., 1985). In preliminary experiments, we tested the feasibility of densities of 2.0, 2.2, and $2.3 \mathrm{~g} \mathrm{~cm}^{-3}$ for POM separation. Separation with a density of $2.0 \mathrm{~g} \mathrm{~cm}^{-3}$ left visually large amounts of POM within the MF. Another experiment on three selected greens from different age groups compared the densities of 2.2 and $2.3 \mathrm{~g} \mathrm{~cm}^{-3}$. The result (not shown) was that ash content of the POM separated by a density of $2.3 \mathrm{~g} \mathrm{~cm}^{-3}$ was even smaller than that of $2.2 \mathrm{~g} \mathrm{~cm}^{-3}$ in two of the greens. This suggested that the difference in the results due to the two

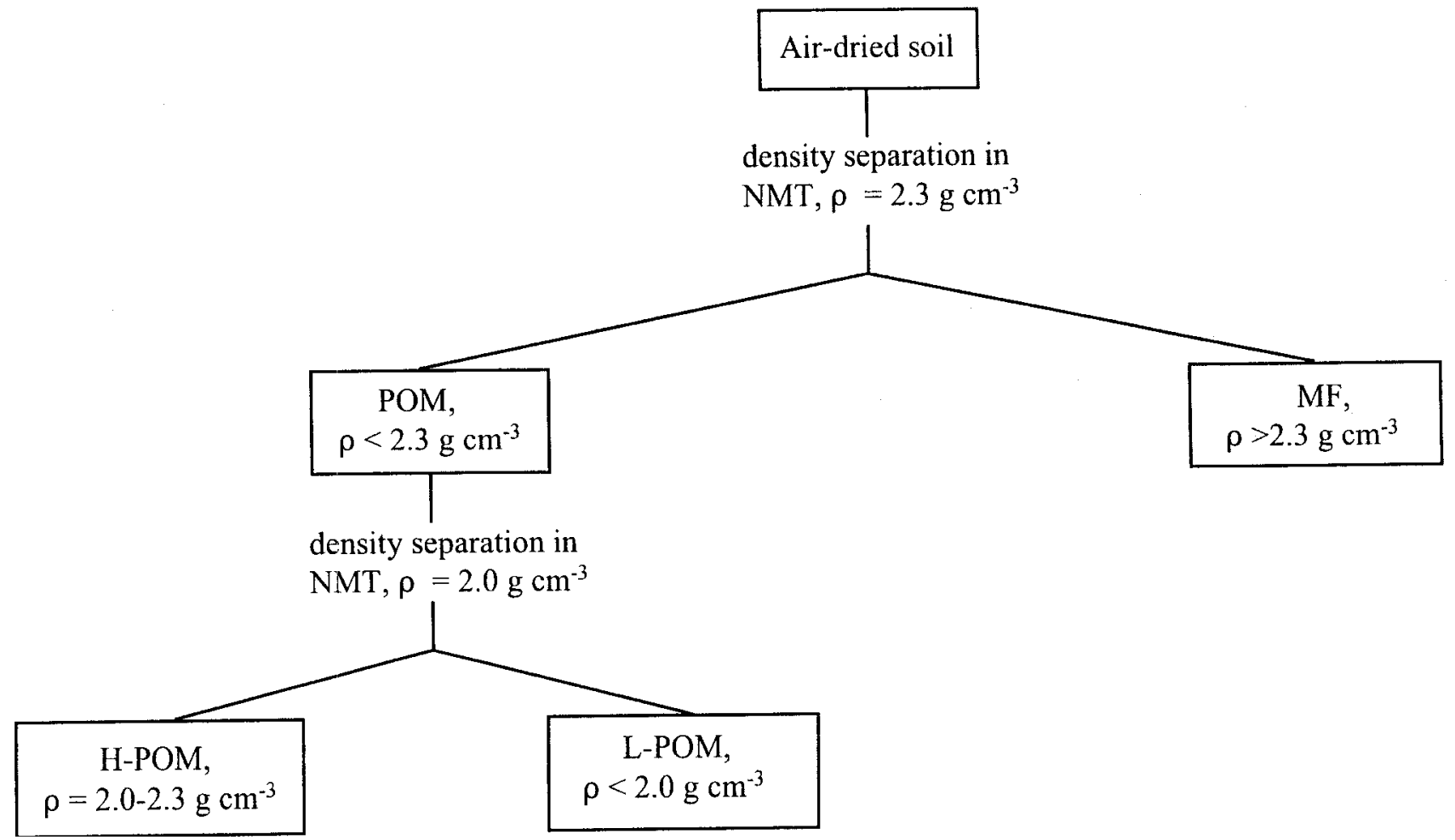

Fig. 1. Soil fractionation sequence for determining the location of microbial biomass (MB). NMT, sodium metatungstate; POM, particulate organic matter; MF, mineral fraction; H-POM, heavy POM; and L-POM, light POM. 
Table 1. Physical and chemical characteristics of soils sampled in 1996, 1997, and 1999. $\dagger$

\begin{tabular}{|c|c|c|c|c|c|c|c|c|c|c|c|c|c|c|}
\hline Golf course & $\begin{array}{c}\text { Green } \\
\text { no. }\end{array}$ & Age $\$$ & Sand & Silt & Clay & pH & Age§ & Total $\mathbf{N}$ & Total C & FA-CII & HA-CII & L-POM\# & H-POM†† & POM \\
\hline \multirow{2}{*}{\multicolumn{8}{|c|}{ Country Club (CC) of }} & $-\mathbf{g ~ k g}^{-}$ & ${ }^{1}$ soil - & $-\mathbf{g ~ C ~ k}$ & $?^{-1}$ soil - & & & \\
\hline & 2 & 3 & 910 & 10 & 80 & 6.6 & 4 & 0.38 & 5.7 & 0.5 & 0.6 & 4.8 & 6.4 & 11.2 \\
\hline Shadow Ridge CC & 7 & 4 & 945 & 25 & 30 & 6.5 & 5 & 0.32 & 6.7 & 0.8 & $\begin{array}{l}0.0 \\
0.9\end{array}$ & $\begin{array}{l}4.0 \\
6.7\end{array}$ & 7.4 & 13.2 \\
\hline North Forty & 8 & 7 & 938 & 20 & 42 & 6.7 & 8 & 0.43 & 7.1 & 1.0 & 1.2 & 6.3 & 11.8 & 18.1 \\
\hline \multirow[t]{2}{*}{ Firethorn CC } & 12 & 12 & 943 & 15 & 42 & 6.5 & 15 & 0.79 & 9.6 & 1.5 & 1.9 & 8.6 & 13.4 & 22.0 \\
\hline & 13 & 12 & 923 & 30 & 47 & 6.4 & 15 & 0.75 & 9.3 & 1.5 & 1.8 & 8.4 & 15.8 & 24.2 \\
\hline \multirow{2}{*}{ Pines CC (Valley) } & 10 & 18 & 891 & 45 & 64 & 6.6 & 21 & 0.82 & 8.6 & 1.0 & 1.2 & 10.0 & 11.1 & 21.1 \\
\hline & 18 & 18 & 902 & 45 & 53 & 6.5 & 21 & 0.84 & 8.4 & 1.3 & 1.4 & 10.3 & 14.2 & 24.5 \\
\hline Mahoney & 10 & 20 & 913 & 35 & 52 & 6.5 & 21 & 1.08 & 12.5 & 1.7 & 2.6 & 18.4 & 35.0 & 53.4 \\
\hline \multirow{2}{*}{ Grand Island Municipal } & 3 & 20 & 922 & 40 & 38 & 6.6 & 21 & 1.10 & 12.1 & 1.4 & 1.7 & 25.6 & 15.7 & 41.3 \\
\hline & 13 & 20 & 914 & 40 & 46 & 6.6 & 21 & 1.09 & 11.8 & 1.6 & 1.9 & 21.3 & 13.1 & 34.4 \\
\hline \multirow[t]{2}{*}{ Bayhills } & 5 & 25 & 934 & 25 & 41 & 6.5 & 28 & 1.14 & 10.8 & 1.5 & 2.0 & 22.8 & 28.4 & 51.2 \\
\hline & 9 & 25 & 914 & 40 & 46 & 6.7 & 28 & 1.19 & 11.1 & 1.4 & 1.9 & 21.6 & 27.7 & 49.3 \\
\hline
\end{tabular}

$\dagger$ Textural class and pH were determined in soils sampled in 1996. The remaining soil characteristics were determined in soils sampled in 1997 and 1999. + Ages of greens sampled in 1996 .

\$ Ages of greens sampled in 1997 and 1999.

II Sum of C in fulvic acid (FA-C) and humic acid (HA-C) fractions of mineral fraction (MF) and particulate organic matter (POM).

\# L-POM, light particulate organic matter.

† H-POM, heavy particulate organic matter.

Sum of the masses of L-POM and H-POM.

densities used was small enough to be masked by the variability between any of the two soil subsamples. Therefore, we chose the density of $2.3 \mathrm{~g} \mathrm{~cm}^{-3}$ to be the optimum density for separation of POM from the MF. This separation yielded a POM fraction with some free sand particles, few aggregates, and a MF with the least amount of POM. The bottles were mixed mechanically by hand for about $1 \mathrm{~min}$. The particles that adhered to the lid and bottle were washed into suspension using NMT solution, and the suspension was allowed to stand for $30 \mathrm{~min}$ before centrifuging at $2000 \mathrm{~g}$ for $30 \mathrm{~min}$ (Golchin et al., 1994). The supernatant with floating particles (POM) was recovered by aspiration (Strickland and Sollins, 1987) and then poured into a Millipore filter funnel fitted with a glassfiber filter paper (Whatman GF/A) and filtered under vacuum. The material remaining in the bottle was designated MF. Total POM and MF were quantitatively washed into appropriately sized centrifuge tubes for $\mathrm{MB}$ and humus $\mathrm{C}$ determinations.

Separation of total POM, after briefly air-drying, into light POM (L-POM) and heavy POM (H-POM) was achieved as outlined above by density separation in NMT $\left(\rho=2.0 \mathrm{~g} \mathrm{~cm}^{-3}\right)$. Preliminary experiments determined that a density of $2.0 \mathrm{~g}$ $\mathrm{cm}^{-3}$ yielded the fraction with the highest proportions of undecomposed plant material although it may have included some partially decomposed plant material as well. The POM fractions were quantitatively washed into appropriately sized centrifuge tubes and extracted immediately for $\mathrm{MB}$; the residue remaining after $\mathrm{MB}$ extraction was then thoroughly rinsed with distilled water to remove residual NMT before mass balance determination. Total POM, L-POM, and H-POM masses reported in Table 1 include associated mineral particles remaining after fractionation. Mass of total POM was determined as the sum of L-POM and H-POM. Mineral fraction, L-POM, and H-POM ash contents of selected samples were determined by keeping samples at $550^{\circ} \mathrm{C}$ for $14 \mathrm{~h}$ and then at $750^{\circ} \mathrm{C}$ for $2 \mathrm{~h}$.

\section{Humus Extraction and Fractionation}

Humus was extracted from MF and total POM with a combined solution of $0.1 M$ sodium hydroxide $(\mathrm{NaOH})$ and $0.1 M$ sodium pyrophosphate $\left(\mathrm{Na}_{4} \mathrm{P}_{2} \mathrm{O}_{7}\right)$ and fractionated into humic acid and fulvic acid fractions at $\mathrm{pH} 1.5$ (Lowe, 1980). Carbon in the extracts was determined by the Walkley-Black wet oxidation method (Allison, 1965). Before organic matter extraction, centrifuge bottles containing MF and total POM were placed in an oven at $60^{\circ} \mathrm{C}$ for several hours to remove the water held by these fractions.

\section{Microbial Biomass Determination}

Total POM, MF, L-POM, and H-POM fractions were quantitatively washed into Teflon tubes, and excess water was decanted. Microbial biomass in the above fractions and from field-moist soil was determined as extractable lipid phosphate (lipid-P) using a modified Bligh and Dyer procedure as described in Kates (1986). Briefly, field-moist soils (1-2 g) and wet samples of the above fractions were extracted with $4 \mathrm{~mL}$ of a single-phase mixture of methanol $\left(\mathrm{CH}_{3} \mathrm{OH}\right)$ and chloroform $\left(\mathrm{CHCl}_{3}\right)$ in a ratio of 2:1 (v/v) and then with $4 \mathrm{~mL}$ of methanol, chloroform, and water in a ratio of 2:1:0.8 (v/v). To separate the phases, $2.5 \mathrm{~mL}$ of chloroform and ammonium sulfate $\left[\left(\mathrm{NH}_{4}\right)_{2} \mathrm{SO}_{4}\right]$ was added to the combined extracts. For soil fractions of different mass, the volumes were adjusted proportionally. The lower chloroform layer was removed and evaporated under $\mathrm{N}_{2}$ to dryness. Phosphate released through perchloric acid digestion was determined by the method of Barlett as described in Kates (1986).

\section{Statistical Analysis}

Linear regression analysis was performed using PC SAS version 6.12 (SAS Inst., Cary, NC). The purpose of the linear regression was to test the model $Y=\beta_{\mathrm{o}}+\beta_{1} X$, where $X$ is the age of green and $Y$ is the soil property, and determine whether the slope was significantly different from zero.

\section{RESULTS AND DISCUSSION}

Soil characteristics of the selected greens sampled in 1996, 1997, and 1999 are given in Table 1. The textural class for all of the greens was sand.

\section{Microbial Biomass of Whole Soil}

Analysis of 47 golf greens sampled in 1996 found a significant positive linear relationship of MB (determined as lipid-P on field-moist soils) to green age ( $Y=$ $19.39+3.54 x, r^{2}=0.87, P=0.001$; Fig. 2A). Contributions of plant lipids to lipid-P were minimal based on the absence of the plant fatty acid, linolenic acid, in lipid extracts from the same soils (data not shown). Furthermore, total bacterial fatty acids were strongly correlated with both lipid-P $\left(r^{2}=0.93\right)$ and green age 


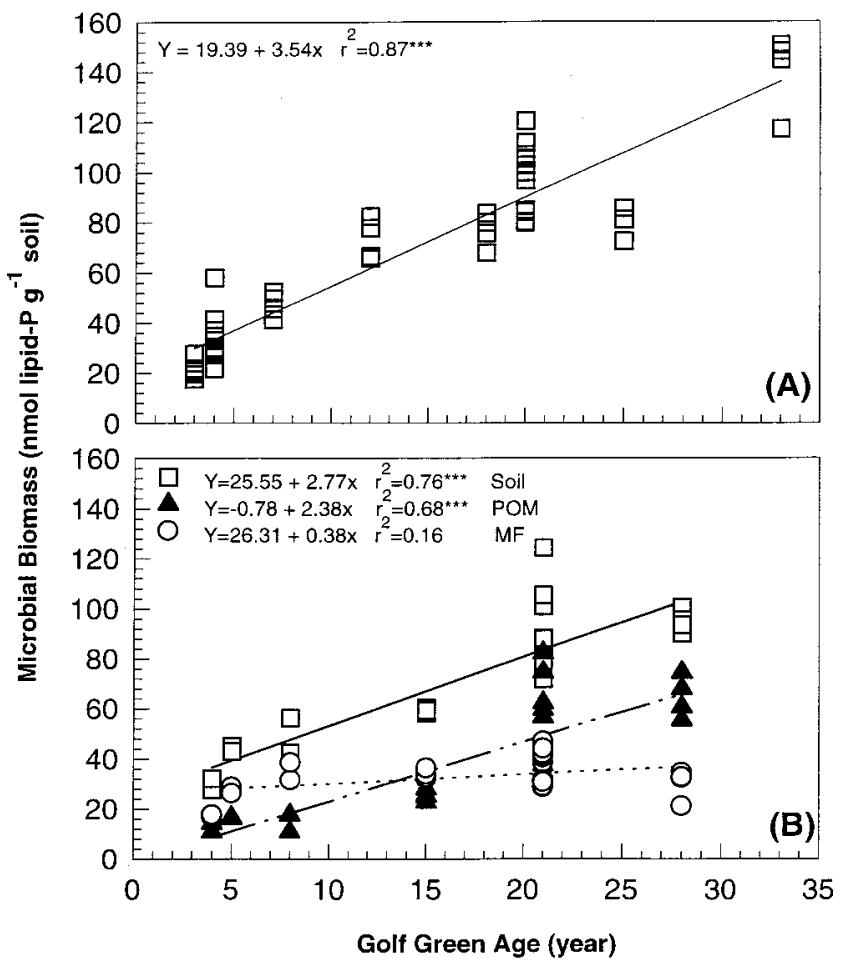

Fig. 2. Microbial biomass (MB) measured as extractable lipid phosphate (lipid-P) on (A) field-moist soils sampled in 1996 and (B) air-dried soils sampled in 1997 and 1999. Microbial biomass on airdried soils includes those of whole soil (as the sum of MB in POM and MF), particulate organic matter (POM), and mineral fraction (MF). Each data point is a single observation. ***Both model and slope are significant at $P=0.001$.

$\left(r^{2}=0.80\right)$, supporting lipid-P as an accurate measure of $\mathrm{MB}$ in these greens (paper in preparation).

The above relationship on field-moist soils compared favorably with the smaller data set on air-dried soils from 12 golf greens $\left(Y=25.55+2.77 x, r^{2}=0.76, P=\right.$ 0.001 ; Fig. 2B). Thus, analysis of air-dried soil fractions accurately reflected MB measured on field-moist soils, and exposure to NMT did not interfere with the lipid extraction. The former is in disagreement with the results of West et al. (1988) and Van Gestel et al. (1991) where the largest biomass $\mathrm{C}$ decline upon air-drying was found for a sandy soil.

Microbial biomass in soil increased significantly with age of green from a low of 27.7 nmol lipid- $\mathrm{P} \mathrm{g}^{-1}$ soil for a 4-yr-old green at the Country Club (CC) of Lincoln to a high of $124.5 \mathrm{nmol}$ lipid- $\mathrm{P} \mathrm{g}^{-1}$ soil for a 21-yr-old one at Mahoney (Fig. 2B). Soil mixes commonly used to construct golf greens contain $<15$ nmol lipid-P g ${ }^{-1}$ soil, which is derived primarily from the peat in the mix (data not shown). The above range in lipid-P equates to a $\mathrm{MB}$ between 249 and $1119 \mathrm{mg} \mathrm{C} \mathrm{kg}^{-1}$ soil based on conversion factors of $50 \mu \mathrm{mol} \mathrm{P} \mathrm{g}{ }^{-1}$ dry cell (White et al., 1979) and $0.45 \mathrm{~g} \mathrm{C} \mathrm{g}^{-1}$ dry cell (Paul and Clark, 1989). For comparison, a silt loam soil in central Iowa cropped to corn (Zea mays L.)-soybean [Glycine max (L.) Merr.] or in virgin tallgrass prairie contained an average biomass, by chloroform fumigation extraction, of 354 and $1145 \mathrm{mg} \mathrm{C} \mathrm{kg}^{-1}$ soil, respectively (DeLuca and Keeney, 1994). Inclusion of MB from the thatch layer would further support golf greens as a reservoir

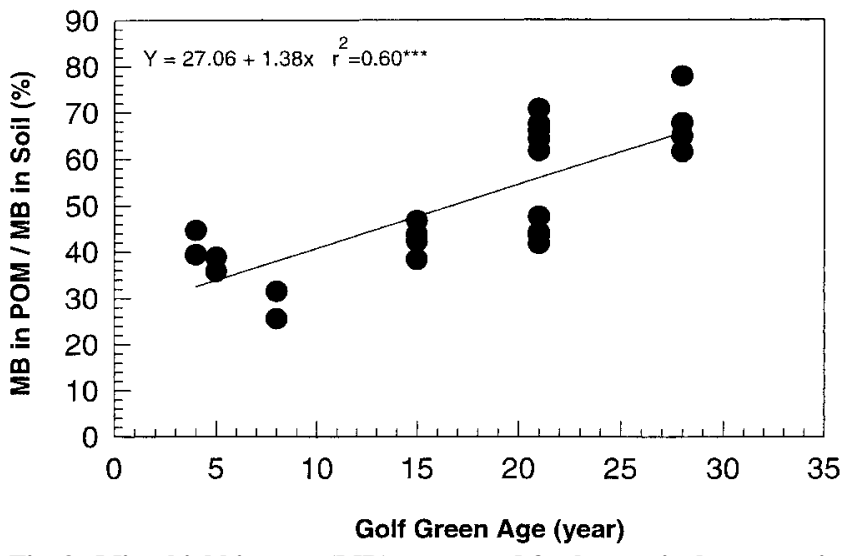

Fig. 3. Microbial biomass (MB) accounted for by particulate organic matter (POM) of air-dried soils from greens sampled in 1997 and 1999. Each data point is a single observation. ***BBoth model and slope are significant at $\boldsymbol{P}=\mathbf{0 . 0 0 1}$.

of $\mathrm{MB}$ as thatch contains an equal or greater number of microorganisms than the mineral soil beneath (Mancino et al., 1993). Preliminary experiments on the above 47 golf greens found that very little of this biomass was associated with water-stable aggregates, which accounted for $<12 \%$ of the soil mass (data not shown). Thus, current models for physical protection of MB within aggregates (Hattori, 1973; Ahmed and Oades, 1984; Tisdall and Oades, 1982) could not account for the accumulation of MB within golf greens.

\section{Microbial Biomass of Mineral Fraction and Particulate Organic Matter}

Microbial biomass tends to congregate near suitable food sources such as decaying plant and animal debris (Haynes and Beare, 1996). As a result, MB may associate with POM. Kanazawa and Filip (1986) found that $66.6 \%$ of total MB, determined by adenosine triphosphate (ATP), was within the light fraction $\left(\rho<1 \mathrm{~g} \mathrm{~cm}^{-3}\right)$ of a loamy sand soil despite the minor contribution of this fraction to the dry soil mass. In addition, Hissett and Gray (1976) showed that $64 \%$ of bacteria in a sandy soil were associated with organic particles. On the other hand, MB could associate with mineral soil particles due to their physiological requirements through binding to thin organic coatings on mineral surfaces (Hissett and Gray, 1976) or because of inhibitory substances within POM. Ahmed and Oades (1984), for example, found insignificant amounts of MB associated with the light fraction $\left(\rho<1.6 \mathrm{~g} \mathrm{~cm}^{-3}\right)$ of a fine sandy loam and a clay soil.

To determine the degree of association of MB with mineral soil particles and plant residues, we separated the soils into two density fractions: $\operatorname{MF}\left(\rho>2.3 \mathrm{~g} \mathrm{~cm}^{-3}\right)$ and POM $\left(\rho<2.3 \mathrm{~g} \mathrm{~cm}^{-3}\right)$. Ash content of MF was $>98 \%$ while $\mathrm{POM}$ fractions contained 70 to $78 \%$ ash, indicating satisfactory separation of POM from MF despite the high density used for separation. Density fraction procedures are often criticized for their shortcomings in successfully separating the mineral-free plant material from more complex soil organic matter (Meijboom et al., 1995) as ash contents of light fractions mostly exceed 50\% (Christensen, 1992).

Microbial biomass in POM increased significantly, 

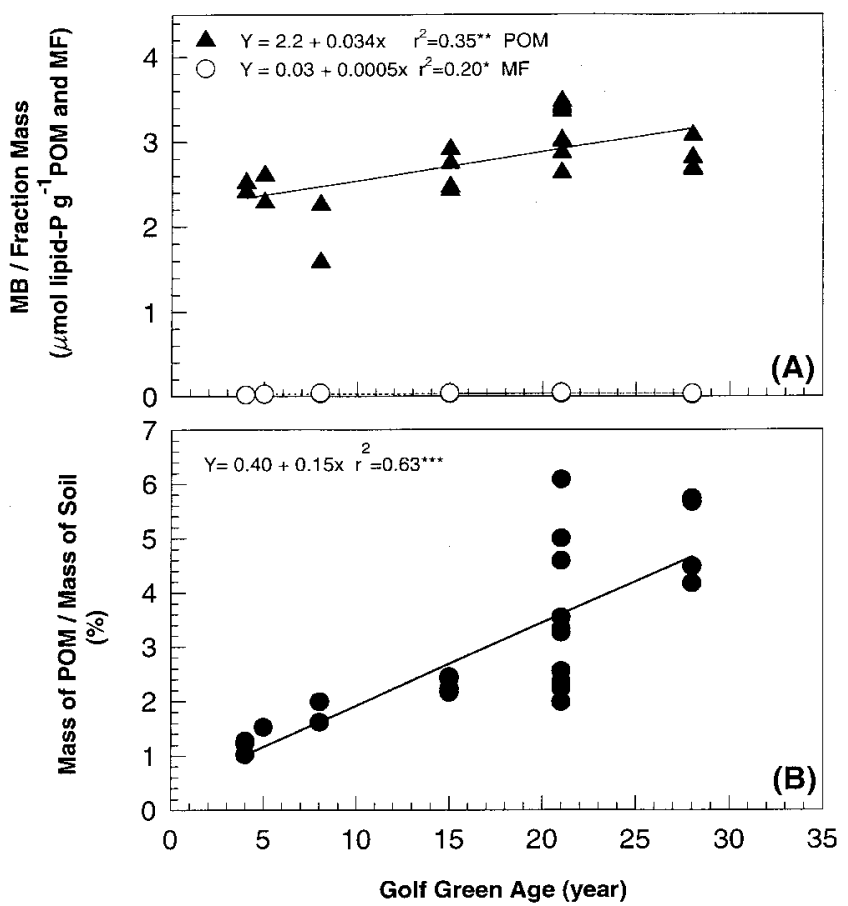

Fig. 4. Relationship to green age of (A) microbial biomass (MB) per unit mass of particulate organic matter (POM) and mineral fraction (MF) and (B) soil mass composed of POM. Soils are air-dried and from greens sampled in 1997 and 1999. Each data point is a single observation. $*$, **, and $* * *$, both model and slope are significant at $P=0.05,0.01$, and 0.001 , respectively.

whereas MB in the MF remained constant with age (Fig. $2 \mathrm{~B})$. This resulted in a significant increase with green age in the portion of total MB included in POM, from $25.6 \%$ for an 8 -yr-old green to $77.8 \%$ for a 28 -yr-old one (Fig. 3). In younger greens ( $\leq 15 \mathrm{yr})$, the MF comprised a large portion of $\mathrm{MB}$ (from 53.2-74.4\%), whereas in older ones $(>15 \mathrm{yr})$, POM comprised a large portion (from $61.5-77.8 \%$ ). An exception to this occurred in 21yr-old greens from Pines CC where MF contained 52.3 to $58.2 \%$ of total MB.

The increase in the portion of total MB in POM with age of green could result from (i) increased MB per unit mass of POM, (ii) increased mass of POM within a unit mass of soil, or (iii) a combination of the two. Microbial biomass per unit mass of POM and MF is calculated and plotted in Fig. 4A. Although significant $\left(r^{2}=0.20, P=0.05\right), \mathrm{MB}$ per unit mass of MF increased slowly with green age at the rate of $0.45 \mathrm{nmol}$ lipid- $\mathrm{P} \mathrm{g}^{-1}$ $\mathrm{yr}^{-1}$. In contrast, MB per unit mass of POM increased significantly $\left(r^{2}=0.35, P=0.01\right)$ with green age at the rate of 34.18 nmol lipid-P $\mathrm{g}^{-1} \mathrm{yr}^{-1}$. Because the above relationships were not strong, we concluded that the increase in the portion of total MB in POM with age resulted mainly from an increase in the soil mass comprised of POM $\left(r^{2}=0.63, P=0.001\right.$; Fig. 4B $)$.

\section{Microbial Biomass of Particulate Organic Matter Fractions}

As the POM was not mineral-free and included few aggregates, our next purpose was to determine whether the amount of $\mathrm{MB}$ within $\mathrm{POM}$ was related to the degree of association of POM with mineral material. Thus, we

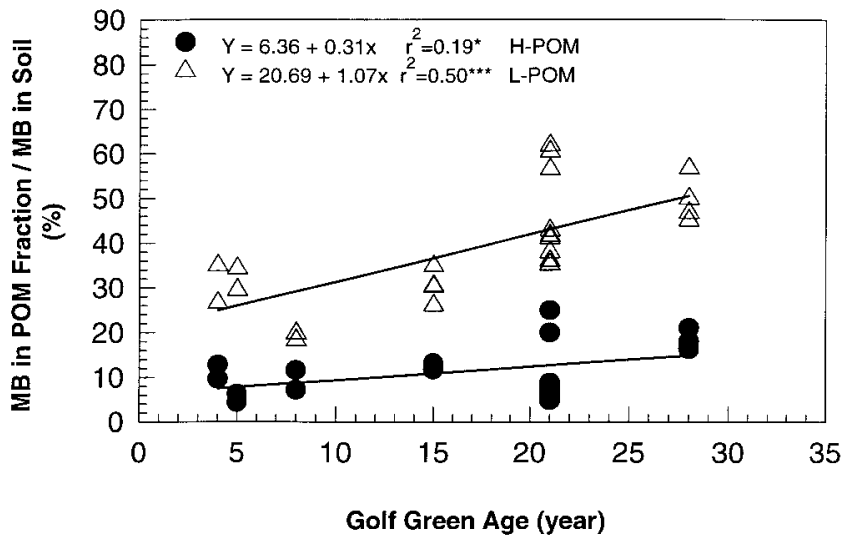

Fig. 5. Microbial biomass (MB) accounted for by heavy particulate organic matter (H-POM) and light POM (L-POM) of air-dried soils from greens sampled in 1997 and 1999. Each data point is a single observation. * and $* * *$, both model and slope are significant at $P=0.05$ and 0.001 , respectively.

separated the POM into L-POM and H-POM. Microscopic examinations (not presented) showed that L-POM included mostly large, undecomposed root and plant fragments with little mineral material, whereas H-POM contained few small aggregates and free sand particles. The L-POM and H-POM comprised up to 25.6 and 35.0 $\mathrm{g} \mathrm{kg}^{-1}$ soil, respectively (Table 1). The range in ash content of L- and H-POM was 37 to $58 \%$ and 86 to $93 \%$, respectively. Meijboom et al. (1995) found that ash content increased with fraction density, suggesting greater decomposition and/or humification in higherdensity fractions (Gregorich et al., 1994). This supports microscopic observations that H-POM is more associated with minerals and appears more altered than L-POM.

Microbial biomass accounted for by L-POM and $\mathrm{H}-\mathrm{POM}$ increased significantly with age from 18.3 to $61.9 \%$ and from 4.4 to $25.0 \%$, respectively (Fig. 5). However, MB was 1.6 to 8.9 times greater in L-POM than in $\mathrm{H}-\mathrm{POM}$, indicating preferential accumulation of $\mathrm{MB}$ in L-POM. This agreed with the findings of Beare et al. (1990) where plant residues contained a larger and more physiologically active biomass than mineral soil. Thus, L-POM was responsible, in a large part, for the increased $\mathrm{MB}$ in total POM.

\section{Humus and its Relationship to Microbial Biomass}

Carbon in fulvic acid (FA-C) and humic acid (HA-C) of whole soil (determined as the sum of $\mathrm{C}$ in POM and $\mathrm{MF}$ ) increased with green age from 0.5 to $1.7 \mathrm{~g} \mathrm{~kg}^{-1}$ soil and from 0.6 to $2.6 \mathrm{~g} \mathrm{~kg}^{-1}$ soil, respectively (Table 1 ). The total soil $\mathrm{C}$ accounted for by FA-C and HA-C in MF decreased from a high of $21.3 \%$ for a 15 -yr-old green at Firethorn CC to a low of $4.8 \%$ for a $21-y r-$ old green at Grand Island Municipal. However, this relationship was not significant (Fig. 6). The total soil C accounted for by FA-C and HA-C in POM significantly increased with age from $10.5 \%$ for a 4 -yr-old green at the CC of Lincoln to $26.4 \%$ for a 21 -yr-old green at Grand Island Municipal (Fig. 6).

Our observations led us to speculate why POM, particularly L-POM, which contained less altered plant residues, was accumulating despite associated biomass. 


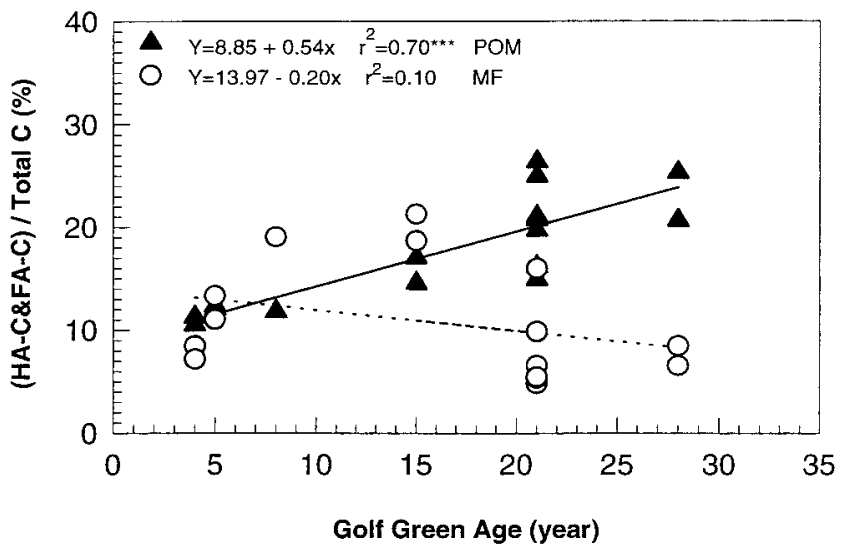

Fig. 6. Total $\mathrm{C}$ comprised of $\mathrm{C}$ in humic acid (HA-C) and fulvic acid (FA-C) fractions of air-dried soils from greens sampled in 1997 and 1999. Each data point is a single observation. POM, particulate organic matter; MF, mineral fraction. $* * *$ Both model and slope are significant at $\boldsymbol{P}=\mathbf{0 . 0 0 1}$.

Some of this accumulation may result from a lag that occurs between the time of organic material deposition and the time of consumption (Elliott et al., 1996). We hypothesized that the factor(s) causing POM to accumulate could also cause associated MB to accumulate. The mechanisms rendering POM more resistant to degradation could relate to the location of soil humus because humus is a relatively stable form of SOM. It is well known that soil microorganisms are essential to humus formation. Therefore, it is conceivable, provided the movement of humic substances is negligible, that the major site of humus accumulation could be related to the predominant microsites for microbial activity in soil. This relationship is supported by Fig. 7 where the amount of humic substances in POM relative to $\mathrm{MF}$ increased significantly $\left(r^{2}=0.92, P=0.001\right)$ with the amount of MB in POM relative to MF. In other words, inclusion of a larger portion of MB in either fraction (POM or MF) is accompanied by inclusion of a larger portion of humus in that particular fraction and vice

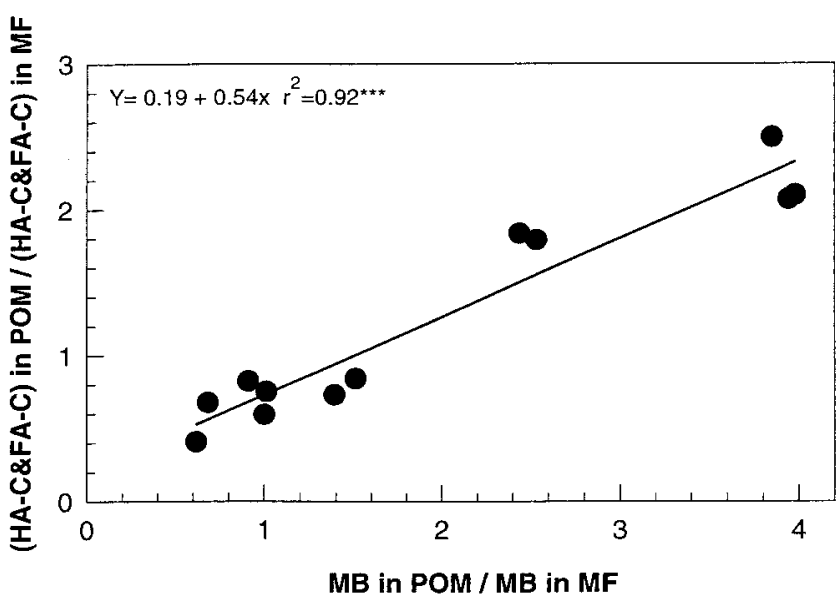

Fig. 7. Relationship of the amount of microbial biomass (MB) in particulate organic matter (POM) relative to mineral fraction (MF) to the amount of humic substances in POM relative to MF. Soils are air-dried and from greens sampled in 1997 and 1999. HA-C, humic acid carbon; FA-C, fulvic acid carbon. $* * *$ Both model and slope are significant at $\boldsymbol{P}=\mathbf{0 . 0 0 1}$. versa. Van Gestel et al. (1996) found a strong correlation $\left(r^{2}=0.77\right)$ between clay content and MB concentration in aggregate-size fractions. Inclusion of organic $\mathrm{C}$ concentration in this relationship increased $r^{2}$ to 0.99 . This may be explained by the fact that soil colloids with high cation exchange capacities, such as clay and humus, influence microbial survival by their greater capacity to adsorb to microbial cells (Amato and Ladd, 1992) in addition to the effect of slow nutrient release from recalcitrant components decomposed at low rates (Van Gestel et al., 1996). Thus, MB accumulation in POM would be favored by microbial growth on readily available substrates that become less accessible as POM fragments and the microbial cells themselves become coated with humus.

\section{CONCLUSIONS}

Soil MB increased as greens aged. This increase was due mainly to accumulation of POM. In younger greens ( $\leq 15 \mathrm{yr}$ ), a large portion of $\mathrm{MB}$ was located within the MF, whereas in older greens $(>15 \mathrm{yr}), \mathrm{MB}$ was preferentially associated with POM. Our study demonstrated that the spatial distribution of MB in the soil structure was determined in large part by the location of humus and vice versa. As microorganisms congregate near suitable food sources, metabolic by-products, i.e., humus, protect plant residues from further decomposition as both residues and microorganisms become coated with humus.

\section{ACKNOWLEDGMENTS}

This work is sponsored in part by the Department of Agronomy and Horticulture, University of Nebraska-Lincoln, Nebraska Turfgrass Foundation (NTF), and O. J. Noer Turfgrass Research Foundation.

\section{REFERENCES}

Ahmed, M., and J.M. Oades. 1984. Distribution of organic matter and adenosine triphosphate after fractionation of soils by physical procedures. Soil Biol. Biochem. 16:465-470.

Alexander, M. 1977. Introduction to soil microbiology, 2nd ed. John Wiley \& Sons, New York.

Allison, L.E. 1965. Organic carbon. p. 1367-1378. In C.A. Black et al. (ed.) Methods of soil analysis. Part 2. Agron. Monogr. 2. ASA, Madison, WI.

Amato, M., and J.N. Ladd. 1992. Decomposition of ${ }^{14}$ C-labelled glucose and legume material in soils: Properties influencing the accumulation of organic residue $\mathrm{C}$ and microbial biomass $\mathrm{C}$. Soil Biol. Biochem. 24:455-464.

Beare, M.H., C.L. Neely, D.C. Coleman, and W.L. Hargrove. 1990. A substrate-induced respiration (SIR) method for measurement of fungal and bacterial biomass on plant residues. Soil Biol. Biochem. 22:585-594.

Cambardella, C.A., and E.T. Elliott. 1992. Particulate soil organicmatter changes across a grassland cultivation sequence. Soil Sci. Soc. Am. J. 56:777-783.

Cambardella, C.A., and E.T. Elliott. 1993. Carbon and nitrogen distribution in aggregates from cultivated and native grassland soils. Soil Sci. Soc. Am. J. 57:1071-1076.

Christensen, B.T. 1992. Physical fractionation of soil and organic matter in primary particle size and density separates. Adv. Soil Sci. 20:1-90.

Deluca, T.H., and D.R. Keeney. 1994. Soluble carbon and nitrogen pools of prairie and cultivated soils: Seasonal variation. Soil Sci. Soc. Am. J. 58:835-840. 
Drijber, R.A., J.W. Doran, A.M. Parkhurst, and D.J. Lyon. 2000. Changes in soil microbial community structure with tillage under long-term wheat-fallow management. Soil Biol. Biochem. 32:14191430.

Elliott, M.L., and E.A. Des Jardin. 1999a. Effect of organic nitrogen fertilizers on microbial populations associated with bermudagrass putting greens. Biol Fertil. Soils 28:431-435.

Elliott, M.L., and E.A. Des Jardin. 1999b. Comparison of media and diluents for enumeration of aerobic bacteria from bermuda grass golf course putting greens. J. Microbiol. Methods 34:193-202.

Elliott, E.T., K. Paustian, and S.D. Frey. 1996. Modeling the measurable or measuring the modelable: A hierarchical approach to isolating meaningful soil organic matter fractions. p. 161-179. In D.S Powlson et al. (ed.) Evaluation of soil organic matter models using existing long-term datasets. NATO ASI Series. Vol. 138. SpringerVerlag, Berlin.

Findlay, R.H., G.M. King, and L. Watling. 1989. Efficacy of phospholipid analysis in determining microbial biomass in sediments. Appl. Environ. Microbiol. 55:2888-2893.

Foster, R.C. 1988. Microenvironments of soil microorganisms. Biol. Fertil. Soils 6:189-203.

Frostegård, Å, A. Tunlid, and E. Bååth. 1991. Microbial biomass measured as total lipid phosphate in soils of different organic content. J. Microbiol. Methods 14:151-163.

Gee, G.W., and J.W. Bauder. 1986. Particle-size analysis. p. 383-411. In A. Klute (ed.) Methods of soil analysis. Part 1. SSSA Book Ser. 5. ASA and SSSA, Madison, WI.

Golchin, A., P. Clarke, J.M. Oades, and J.O. Skjemstad. 1995. The effects of cultivation on the composition of organic matter and structural stability of soils. Aust. J. Soil Res. 33:975-993.

Golchin, A., J.M. Oades, J.O. Skjemstad, and P. Clarke. 1994. Study of free and occluded particulate organic matter in soils by solid state ${ }^{13} \mathrm{C} \mathrm{CP} / \mathrm{MAS}$ NMR spectroscopy and scanning electron microscopy. Aust. J. Soil Res. 32:285-309.

Gregorich, E.G., M.R. Carter, D.A. Angers, C.M. Monreal, and B.H. Ellert. 1994. Towards a minimum data set to assess soil organic matter quality in agricultural soils. Can. J. Soil Sci. 74:367-385.

Gregorich, E.G., and H.H. Janzen. 1996. Storage of soil carbon in the light fraction and macroorganic matter. p. 167-190. In M.R. Carter and B.A. Stewart (ed.) Structure and organic matter storage in agricultural soils. Advances in soil science. CRC, Lewis Publ., Boca Raton, FL.

Hattori, T. 1973. Microbial life in the soil. An introduction. Marcel Dekker, New York.

Hattori, T. 1988. Soil aggregates as microhabitats of microorganisms. Rep. Inst. Agric. Res., Tohuku Univ. 37:23-36.

Haynes, R.J., and M.H. Beare. 1996. Aggregation and organic matter storage in mesothermal, humid soils. p. 213-262. In M.R. Carter and B.A. Stewart (ed.) Structure and organic matter storage in agricultural soils. Advances in soil science. CRC, Lewis Publ., Boca Raton, FL.

Hill, T.C.J., E.F. Mcpherson, J.A. Harris, and P. Birch. 1993. Microbial biomass estimated by phospholipid in soils with diverse microbial communities. Soil Biol. Biochem. 25:1779-1786.

Hissett, R., and T.R.G. Gray. 1976. Microsites and time changes in soil microbe ecology. p. 23-39. In J.M. Anderson and A. Macfadyen (ed.) The role of terrestrial and aquatic organisms in decomposition processes. Blackwell Sci. Publ., Malden, MA.

Jastrow, J.D., T.W. Boutton, and R.M. Miller. 1996. Carbon dynamics of aggregate-associated organic matter estimated by carbon-13 natural abundance. Soil Sci. Soc. Am. J. 60:801-807.

Jordan, D., R.J. Kremer, W.A. Bergfield, K.Y. Kim, and V.N. Cacnio.
1995. Evaluation of microbial methods as potential indicators of soil quality in historical agricultural fields. Biol. Fertil. Soils 19:297-302.

Kanazawa, S., and Z. Filip. 1986. Distribution of microorganisms, total biomass, and enzyme activities in different particles of brown soil. Microbiol. Ecol. 12:205-215.

Kates, M. 1986. Techniques of lipidology: Isolation, analysis and identification of lipids. p. 106-107, 114-115. In R.H. Burdon and P.H. van Kippenberg (ed.) Laboratory techniques in biochemistry and molecular biology. Vol. 3. Part 2. Elsevier, New York.

Liu, L.X., T. Hsiang, K. Carey, and J.L. Eggens. 1995. Microbial populations and suppression of dollar spot disease in creeping bentgrass with inorganic and organic amendments. Plant Dis. 79:144147.

Lowe, L.E. 1980. Humus fraction ratios as a means of discriminating between horizon types. Can. J. Soil Sci. 60:219-229.

Mancino, C.F., M. Barakat, and A. Maricic. 1993. Soil and thatch microbial populations in an $80 \%$ sand: $20 \%$ peat creeping bentgrass putting green. HortScience 28:189-191.

Meijboom, F.W., J. Hassink, and M. Van Noordwijk. 1995. Density fractionation of soil macroorganic matter using silica suspensions. Soil Biol. Biochem. 27:1109-1111.

Monroizer, J.L., J.N. Ladd, A.W. Fitzpatrick, R.C. Foster, and M. Raupach. 1991. Components and microbial biomass content of size fractions in soils of contrasting aggregation. Geoderma 49:37-62.

Nelson, E.B. 1992. Biological control of turfgrass diseases. Inf. Bull. 220. Cornell Coop. Ext., Cornell Univ., Ithaca, NY.

Nelson, E.B. 1994. More than meets the eye: The microbiology of turfgrass soils. Turf Grass Trends 3:1-7.

Paul, E.A., and F.E. Clark. 1989. Soil microbiology and biochemistry. Academic Press, San Diego, CA.

Shaymukhametov, M.S., N.A. Titova, L.S. Travnikova, and Y.M. Labenets. 1985. Use of physical fractionation methods to characterize soil organic matter. Sov. Soil Sci. 16:117-128.

Strickland, T.C., and P. Sollins. 1987. Improved method for separating light- and heavy-fraction organic material from soil. Soil Sci. Soc Am. J. 51:1390-1393.

Thomas, G.W. 1996. Soil pH and soil acidity. p. 475-490. In D.L. Sparks (ed.) Methods of soil analysis. Part 3. SSSA Book Ser. 5. SSSA and ASA, Madison, WI.

Tisdall, J.M., and J.M. Oades. 1982. Organic matter and water-stable aggregates in soils. J. Soil Sci. 33:141-163.

Turchenek, L.W., and J.M. Oades. 1979. Fractionation of organomineral complexes by sedimentation and density techniques. Geoderma 21:311-343.

Turgeon, A.J. 1996. Turfgrass management, 4th ed. Prentice Hall, Upper Saddle River, NJ.

Van Gestel, M., J.N. Ladd, and M. Amato. 1991. Carbon and nitrogen mineralization from two soils of contrasting texture and microaggregate stability: The influence of sequential fumigation, drying and storage. Soil Biol. Biochem. 23:313-322.

Van Gestel, M., R. Merckx, and K. Vlassak. 1996. Spatial distribution of microbial biomass in microaggregates of a silty-loam soil and the relation with the resistance of microorganisms to soil drying. Soil Biol. Biochem. 28:503-510.

West, A.W., G.P. Sparling, T.W. Speir, and J.M. Wood. 1988. Comparison of microbial C, N-flush and ATP, and certain enzyme activities of different textured soils subject to gradual drying. Aust. J. Soil Res. 26:217-229.

White, D.C., R.J. Bobbie, J.S. Herron, J.D. King, and S.J. Morrison 1979. Biochemical measurements of microbial mass and activity from environmental samples. p. 69-81. In J.W. Costerton and R.R. Colwell (ed.) Native aquatic bacteria: Enumeration, activity and ecology. ASTM STP 695. Am. Soc. for Testing and Materials, Philadelphia. 